\title{
Cholesterol-loaded cyclodextrin in fresh goat sperm improves cryosurvival rates*
}

\section{Colesterol em sêmen caprino melhora a criopreservação}

\author{
Wildelfrancys Lima de Souza, ${ }^{* *}$ Elenice Andrade Moraes, ${ }^{* *}$ Jonathan Maia Silva Costa, ${ }^{* *}$ James K. Graham ${ }^{* * *}$
}

\begin{abstract}
This study evaluated the effect of adding different concentration of cholesterol-loaded-cyclodextrin (CLC) on sperm quality after thawing. Thirty ejaculates were diluted, centrifuged and resuspended to 120 million cells $/ \mathrm{mL}$ in a Tris diluent. Semen was treated with 0 (Control), $0.75,1.5,3.0,4.5,6.0$ or $7.5 \mathrm{mg}$ of CLC. Then, the samples were cooled at $4{ }^{\circ} \mathrm{C}$ for $2 \mathrm{~h}$, diluted with Tris-egg yolk and $2 \%$ glycerol, packaged into $0.5 \mathrm{~mL}$ straws, frozen in liquid nitrogen $\left(\mathrm{N}_{2}\right)$ vapor for 20 min before being plunged into $\mathrm{N}_{2}$. Straws were thawed at $37^{\circ} \mathrm{C}$ for $30 \mathrm{sec}$, and evaluated for thermal resistance test (TRT); progressive motility using CASA; hypoosmotic test and for binding capacity of sperm to perivitelline membrane (PM). The variables were determined using ANOVA at $5 \%$ probability. Higher percentage of motile sperm were maintained after thawing and TTR when $0.75 \mathrm{mg}$ CLC was added, evaluated at 0,60 and 120 min of incubation $(50.4,33.8$ and $22.5 \%$, respectively) compared to other treatments $(P<0.05)$. The percentage of coiling was higher in sperm treated with 6.0 and $7.0 \mathrm{mg}$ of CLC than other treatments $(\mathrm{P}<0.05)$. Addition of $0.75 \mathrm{mg}$ CLCs also resulted in more sperm binding to the PM after cryopreservation than control sperm (166 vs $65 ; \mathrm{P}<0.05$ ). However, when the spermatozoa binding potential was determined on a motile sperm basis by dividing the average number of spermatozoa bound to PM for each bucks by the percentage of motile spermatozoa, CLC treatment provided higher binding efficiency (1.52) than control $(1.00 ; P<0.05)$. In conclusion, CLCs improved the percentage of post-thaw of motility in caprine sperm as well as increased the number of sperm that bind to PM. Addition of $0.75 \mathrm{mg}$ of CLC to caprine sperm prior to cryopreservation improved the quality sperm motility for up to $2 \mathrm{~h}$.
\end{abstract}

Keywords: cyclodextrin, frozen, membrane, spermatozoa, seminal quality.

\section{Resumo}

Este estudo teve como objetivo avaliar o efeito da adição do colesterol carreado com a ciclodextrina (CCC) sobre a melhoria da qualidade espermática após a descongelação. Trinta ejaculados foram diluídos, centrifugados e ressuspendidos com Tris para concentração de $120 \times 10^{6}$ células $/ \mathrm{mL}$. O sêmen foi tratado com $0,0,75,1,5,3,0,4,5,6,0$ ou $7,5 \mathrm{mg}$ de CCC. Em seguida, as amostras foram resfriadas a $4^{\circ} \mathrm{C}$ durante 2 horas, diluídas com Tris-Gema de ovo e $2 \%$ de glicerol, envasadas e colocadas sobre o vapor do nitrogênio líquido $\left(\mathrm{N}_{2}\right)$ por 20 min e depois mergulhadas no $\mathrm{N}_{2}$. As amostras foram descongeladas a $37^{\circ} \mathrm{C}$ por $30 \mathrm{~s}$, e avaliadas quanto: o teste de termorresistência (TRT); motilidade progressiva utilizando CASA; teste hiposmótico e a capacidade de ligação dos espermatozoides à membrana perivitelina (MP). As variáveis foram analisadas por meio da ANOVA e os tratamentos comparados a $5 \%$ de probabilidade. A motilidade dos espermatozoides $(50,4 ; 33,8$ e $22,5 \%)$ foi maior nas amostras tratadas com 0,75 mg de CCC após 0,60 e 120 min de incubação quando comparado com demais tratamentos $(P<0,05)$. As amostras tratadas com 6,0 e 7,0 mg de CCC apresentaram maior dobramento de cauda que os demais tratamentos $(P<0,05)$. A capacidade de ligação dos espermatozoides a MP foi maior no tratamento com $0,75 \mathrm{mg} \mathrm{CCC}$ comparado ao controle $(166$ vs $65 ; \mathrm{P}<0,05)$. No entanto, quando o potencial de ligação dos espermatozoides foi determinado dividindo o número médio de espermatozoides ligados a MP sobre o percentual de espermatozoides móveis, o tratamento com CCC proporcionou maior eficiência $(1,52)$ do que o controle $(1,00 ; P<0,05)$. A adição de $0,75 \mathrm{mg}$ de CCC no sêmen fresco de caprino antes da criopreservação melhorou a motilidade espermática após a criopreservação até 2 horas.

Palavras-chave: ciclodextrina, congelado, espermatozoide, membrana, qualidade seminal.

\section{Introduction}

The ability to cryopreserve spermatozoa from all of the domestic species is challenging. Even though all of the cells must endure similar physical stresses associated with the cryopreservation processes, sperm from the different species are very different in size, shape and lipid composition, all of which affect cryosurvival. Cryopreservation induces partially irreversible damage to sperm that result in reduced fertility for frozen sperm from many compared to fresh or cooled. Damage occurs to sperm membranes when the spermatozoa are cooled to $5^{\circ} \mathrm{C}$ and during cryopreservation (Moraes et al. 2015).

*Recebido em 01 de julho de 2015 e aceito em 3 de maio de 2016.

**Department of Animal Science, Federal University of San Francisco Valley, Petrolina, PE, 56304205, Brazil.

${ }^{* * *}$ Animal Reproduction and Biotechnology Laboratory, Colorado State University, Fort Collins, CO 80523, USA.

Corresponding author: elenice.moraes@univasf.edu.br 
The cooling process induces lipid and protein rearrangements within the cell membranes when they are cooled from 22 to $1 \cdot \mathrm{C}$ (Mocé et al. 2010a). This variation was induced by the membrane changing from the fluid to the gel-state at low temperature (Lee et al. 2015). Thermotropic phase transitions are considered to be one of the mains reasons for reduced viability and fertility of sperm during the cryopreservation (Lee et al. 2015). Thus, when a cryopreservation protocol is optimized for sperm of one species, it may not be ideal for sperm of other species.

Cholesterol plays important roles in both sperm cold-shock resistance and sperm functionality and capacitation (Moraes et al. 2015). Therefore, cholesterol has been used in the cryopreservation protocols for sperm from several cold-shock sensitive species (Mocé et al. 2010a). Recently, techniques to increase sperm membrane cholesterol levels have increased cryosurvival rates of sperm (Müller et al. 2008; Mocé et al. 2010b; Yildiz et al. 2015).

Cholesterol may be easily incorporated into or extracted from the plasma membranes of cells using cyclodextrins (Mocé et al. 2010a). It is possible to have the same occurrence for cholestanol because its chemical structure resembles that of cholesterol, with a double bond missing at the 5-6 position of the ring (Moraes et al. 2010).

Cyclodextrins, cyclic heptasaccharides consisting of beta (1-4)-glucopyranose units, are water soluble but have a hydrophobic center and can transport cholesterol into or out of membranes down to concentration gradient (Moraes et al. 2010). However, this procedure has not yet been optimized for goat sperm, nor is it known how the cholesterol regulates the cryosurvival of goat sperm and the function of physiology of the membrane.

Thus, understanding of the regulation of the cholesterol and the protection of sperm membrane and viability are important to the overall understanding cryosurvival during sperm cryopreservation. This study was conducted to determine if cholesterol-loaded cyclodextrin was able to increase goat sperm cryosurvival.

\section{Materials and methods}

\section{Local}

The experiment was conducted at the Department of Animal Production and Center of Research of Swine, Native species and Wild Animals (CPSENS, Brazil) of the Agricultural Sciences Campus of the Federal University of São Francisco Valley (UNIVASF, Brazil). The climate of the region, according to the Köppen-Geiger (2007) classification, is of the tropical and subtropical steppe type (Bsh), characterized by high temperatures, low humidity, high evaporation rates, and especially marked by the scarcity and irregularity in rainfall distribution. According to the Laboratory of Meteorology and Bioclimatology of the UNIVASF, during the experimental period, from March to July of 2015, the average daily temperature was $25^{\circ} \mathrm{C}$ and the average relative air humidity was $62.7 \%$

\section{Animals}

Five non-descript breed (NDB) bucks, with an average age of 2 years and body weight $29.0 \mathrm{~kg}$, were housed in covered individual stalls with ad libitum water. The diet was offered as a complete mixed ration at 0800 and $1500 \mathrm{~h}$ and consisted of chopped elephant grass as fed (Pennisetum purpureum) and a ground corn and soybean meal-based concentrate at roughage to concentrate ratio of 40:60 (Table 1).

\section{Materials}

All chemicals were reagent grade and purchased from SigmaAldrich (St. Louis, MO, USA), except for Hoechst 33342 which was purchased from ICN, Biomedicals, Inc. (Aurora, OH, USA).

Table 1: Proportion of ingredients and composition of the diet

\begin{tabular}{lc}
\hline Ingredients & \% dry matter \\
\hline Elephant grass & 40.0 \\
Ground com & 28.6 \\
Soybean meal & 29.5 \\
Sodium cloride & 0.5 \\
Commercial premix ${ }^{\mathrm{a}}$ & 1.1 \\
Urea & 0.3 \\
Composition & \\
Dry matter & 63.8 \\
Organic matter, \%DM & 92.7 \\
Ash, \%DM & 7.3 \\
Crude protein, \%DM & 17.9 \\
Ether extract, \%DM & 2.9 \\
Neural detergent fiber, \%DM & 37.9 \\
Non-fibrous carbohydrates, \%DM & 33.9 \\
Digestible energy, Mcal/kg DM ${ }^{\mathrm{b}}$ & 1.9 \\
\hline
\end{tabular}

${ }^{a}$ Contains $200 \mathrm{~g} \mathrm{Ca} / \mathrm{kg}, 70 \mathrm{~g} \mathrm{P} / \mathrm{kg}, 28.2 \mathrm{~g} \mathrm{k} / \mathrm{kg}, 10 \mathrm{~g} \mathrm{~S} / \mathrm{kg}, 5000 \mathrm{mg} \mathrm{Mg} / \mathrm{kg}$, $25 \mathrm{mg} \mathrm{Co} / \mathrm{kg}, 440 \mathrm{mg} \mathrm{Cu} / \mathrm{kg}, 340 \mathrm{mg} \mathrm{Fe} / \mathrm{kg}, 1480 \mathrm{mg} \mathrm{Mn} / \mathrm{kg}, 20 \mathrm{mg} \mathrm{Se} / \mathrm{kg}$, $3010 \mathrm{mg} \mathrm{Zn} / \mathrm{kg}, 40 \mathrm{mg} \mathrm{I} / \mathrm{kg}, 6 \mathrm{mg} \mathrm{Cr} / \mathrm{kg}, 100 \mathrm{~g} \mathrm{Na} / \mathrm{kg}, 250,000 \mathrm{IU}$ vitamin A/ $\mathrm{kg}, 40,000 \mathrm{IU}$ vitamin D3/kg, and $350 \mathrm{IU}$ vitamin $\mathrm{E} / \mathrm{kg}$

${ }^{\mathrm{b}}$ Means of digestible and metabolizable energy of the ad libitum feeding calculated according to the NRC (2007).

\section{Preparation of CLCs}

Methyl- $\beta$-cyclodextrin was loaded with cholesterol as described by Purdy \& Graham (2004b). Briefly, a $0.45 \mathrm{~mL}$ aliquot of cholesterol (200 mg/mL in chloroform) was added $1 \mathrm{~g}$ of methyl$\beta$-cyclodextrin dissolved in $2 \mathrm{~mL}$ of methanol and the solution stirred until clear. The mixture was then poured into a glass Petri dish and the solvents removed using a stream of nitrogen gas. The resulting crystals were allowed to dry for an additional 24 $\mathrm{h}$, at which time they were removed from the dish and stored in a glass container at $22^{\circ} \mathrm{C}$. A working solution of the cholesterol- 
loaded cyclodextrin was prepared by adding $50 \mathrm{mg}$ of $\mathrm{CLC}$ to 1 $\mathrm{mL}$ of TALP (Graham et al. 1986 ) at $37^{\circ} \mathrm{C}$ and mixing the solution briefly using a vortex mixer.

\section{Semen collection, processing and cryopreservation}

Ejaculates from five bucks (2 times/week) were collected using Minitub model artificial vagina and the semen was used within $45 \mathrm{~min}$ of collection. All animals were maintained under the guidelines presented by the UNIVASF's Animal Care and Use Committee (Protocol \#27091063). Immediately after collection, ejaculates were kept in a water bath at $35-37^{\circ} \mathrm{C}$ until their assessment.

Single ejaculates from male with $<50 \%$ total motility were used. The sperm concentration from each ejaculate was determined using a photometer (SpermaCue ${ }^{\circledR}$, Minitube, Brazil), when the semen was diluted $(1 / 400 ; \mathrm{v} / \mathrm{v})$ with a sodium chloride solution $(0.9 \% ; \mathrm{v} / \mathrm{v})$. The total and progressively motile spermatozoa were determined using computer-assisted sperm analysis system (CASA; IVOS, Hamilton-Thorne Biosciences, Beverly, MA, USA). Briefly, the vigor was estimated by light microscopy at $400 \mathrm{x}$ using a very small drop $(10 \mu \mathrm{L})$ of spermatozoa was placed on a preheated $\left(37^{\circ} \mathrm{C}\right)$ slide and categorized (ranging from 0 until 5 , where zero equal total immobility sperm and five equal intense movements.

After this, the semen was diluted $(1 / 1 ; \mathrm{v} / \mathrm{v})$ in Tris diluent $(200 \mathrm{mM}$ Tris, $65 \mathrm{mM}$ citric acid, $55 \mathrm{mM}$ glucose) and centrifuged at $800 \mathrm{x}$ $\mathrm{g}$ for $10 \mathrm{~min}$ to seminal plasma removal. The sperm pellets were resuspended in Tris to a concentration of $120 \times 10^{6} \mathrm{sperm} / \mathrm{mL}$. The sperm sample was then divided into seven aliquots and each aliquot treated with 0 (No additive, control), $0.75,1.5,3.0,4.5,6.0$ or $7.5 \mathrm{mg} \mathrm{CLC} / 120 \times 10^{6} \mathrm{sperm} / \mathrm{mL}$. The sperm incubated for 15 min at $22^{\circ} \mathrm{C}$. After, the samples were cooled to $4^{\circ} \mathrm{C}$ over a 120 min period. The samples were then diluted with Tris-Egg Yolk diluent containing $2 \%$ glycerol. The sperm were then packaged into $0.5 \mathrm{~mL}$ French straws, frozen in static liquid nitrogen vapor ( $4.5 \mathrm{~cm}$ above the liquid nitrogen) for $20 \mathrm{~min}$ before being plunged into liquid nitrogen for storage.

Straws were thawed in $37^{\circ} \mathrm{C}$ water for 30 seconds. Subsamples from each treatment were used to determine sperm motility, thermal resistance test (TRT), osmotic tolerance (HOST) and the ability of sperm to binding to the chicken egg perivitelline membrane using CASA, microscope optic and fluorescence microscopy, respectively.

\section{Thermal resistance test - TRT}

Thermal resistance test was performed after thawing. A volume of $0.5 \mathrm{~mL}$ of semen from each treatment was placed into $1.5 \mathrm{~mL}$ in eppendorf tubes and incubated in a water bath at $37^{\circ} \mathrm{C}$ for $3 \mathrm{~h}$. After 0,60, 120 and $180 \mathrm{~min}$, subsamples were evaluated for sperm progressive motility. It was analyzed the straight progressive spermatic motility and spermatic vigor.

Subsample was analyzed by CASA system for the percentages of total and progressively motile cells. A $6.5 \mu \mathrm{L}$ drop of spermatozoa from each sample was placed on a $37{ }^{\circ} \mathrm{C}$ preheated Cell-Vu microscope slide (Millennium Sciences, Inc., New York) and a minimum of 400 spermatozoa per sample were analyzed.

\section{Hypoosmotic swelling test - HOST}

HOST was conducted by adding $10 \mu \mathrm{L}$ of sperm to $2 \mathrm{~mL}$ of hypoosmotic solution (dehydrated sodium citrate and fructose solution with $150 \mathrm{mOsm} / \mathrm{kg}$ ) and incubated for $1 \mathrm{~h}$ in a water bath at $37^{\circ} \mathrm{C}$. After incubation, $20 \mu \mathrm{L}$ of the solutions containing semen were evaluated using a phase-contrast microscope at 1000x of magnification. A total of 100 spermatozoa were counted per ejaculated. Spermatozoa were classified as reactive (coiled tail) or not reactive (straight tail) according to description used by Neild et al. (2000). Spermatozoa reactive rate was calculated subtracting the percentage of coiled tails after hypoosmotic incubation by percentage of coiled tails found in morphological exam in natura semen (Melo \& Henry, 1999).

\section{Chicken egg perivitelline membrane binding assay Perivitelline membrane preparation}

The ability of buck sperm to bind to the perivitelline membrane (PM) was conducted using the chicken egg perivitelline membrane (EPM) described by Barbato et al. (1998). PM was prepared by separating the egg yolks from the egg whites, and removing excess white from the yolk using a paper towel. The intact yolk was placed onto a piece of parafilm, the membrane ruptured and the yolk gently washed away using TALP, while keeping the membrane on the parafilm. The membrane was washed from the parafilm with TALP and placed into a $10 \mathrm{~mL}$ glass vial. The membrane was then washed several times with TALP, until the solution was clear and no visible yolk was present. The PM was then placed into a Petri dish, gently spread to a single layer and then cut into small squares $(1 \times 1 \mathrm{~cm})$, using a scalpel and a spectrophotometer cuvette as a template. Each perivitelline piece was then placed into a culture tube $(16 \times 100$ $\mathrm{mm}$ ) containing $1 \mathrm{~mL}$ of TALP.

\section{Perivitelline membrane binding assay}

The ability of sperm, from each treatment, to bind to a zona pellucida was evaluated using the PM squares. Each PM piece was inseminated with a total of 10,000 fresh sperm from the better treatment. The membranes and sperm were co-incubated for $2 \mathrm{~h}$, at $37^{\circ} \mathrm{C}$ in an atmosphere of $5 \% \mathrm{CO}_{2}$ in air, and the tubes gently shaken every 30 min to keep the membranes from folding. One hour prior to the end of the incubation, $1 \mu \mathrm{L}$ of Hoechst 33342 (1 $\mathrm{mg} / \mathrm{mL}$ in water) was added to each of the tubes to stain the sperm. After incubation, each membrane was placed into a new tube containing $1 \mathrm{~mL}$ TALP and the membranes washed five times to remove any unbound sperm. Each PM square was then placed onto a glass slide, gently spread to remove any folds, a coverslip was added and the slide examined using fluorescence microscopy (excitation $340-380 \mathrm{~nm}$, emission $435-485 \mathrm{~nm}$ ) at 400 times magnification.

Using an ocular grid $\left(0.2 \mathrm{~mm}^{2}\right)$, the number of sperm bound to the membrane in six predetermined fields of each membrane piece was determined. The relative number of sperm bound per membrane for the better treatment within a replicate was calculated, by dividing the total number of sperm bound to that particular PM by the number of sperm bound by control sperm (no cyclodextrin treatment) to a membrane piece from the same yolk membrane. The relative mean from three duplicate membranes was determined for each ejaculate. 


\section{Statistical analysis}

The Lilliefors test was used to evaluate normality of the data. The homogeneity of variance was studied, using the Cochran-Bartlett test. Means, standard deviations and variation coefficient were calculated for all studied variables. The percentages of motility, TRT, HOST and the binding efficiency of sperm to salt-stored EPM were analyzed by analysis of variance and treatment differences separated by Student-Newman-Keuls (SNK) mean separation technique (SAS 2008). Sperm binding data were transformed, prior to analysis, by square root transformation to adjust for unequal variances. To find the binding potential of an individual sperm cell, these data were also normalized to take into account the percentage of motile sperm that were added to each PM, by dividing the number of sperm bound to a PM by the percentage of motile sperm in that sample.

\section{Results}

Treating fresh goat sperm with $0.75 \mathrm{mg}$ of CLC before cryopreservation resulted in higher percentages of motile sperm in zero-hour incubation than control sperm (50 and $31 \%$, respectively; Table 2; $\mathrm{P}<0.05)$. Difference was detected in complementary test by TRT (Table 2; $\mathrm{P}<0.05$ ).

Table 2: Progressive motility of reactive spermatozoa treated with CLC or not (0 mg; control) after thermal resistance test at $0,60,120$ and 180 min of incubation time

\begin{tabular}{ccccc}
\hline $\begin{array}{c}\text { CLC } \\
(\mathrm{mg})\end{array}$ & $\begin{array}{c}\mathrm{MOT} / \mathrm{tOMIN} \\
(\%)\end{array}$ & $\begin{array}{c}\mathrm{MOT} / \mathrm{t} 60 \mathrm{MIN} \\
(\%)\end{array}$ & $\begin{array}{c}\mathrm{MOT} / \mathrm{t} 120 \mathrm{MIN} \\
(\%)\end{array}$ & $\begin{array}{c}\mathrm{MOT} / \mathrm{t} 180 \mathrm{MIN} \\
(\%)\end{array}$ \\
\hline 0 & $31.50^{\mathrm{EF}, \mathrm{a}}$ & $16.60^{\mathrm{C}, \mathrm{b}}$ & $17.50^{\mathrm{D}, \mathrm{b}}$ & $11.33^{\mathrm{A}, \mathrm{c}}$ \\
0.75 & $50.40^{\mathrm{A}, \mathrm{a}}$ & $22.50^{\mathrm{A}, \mathrm{c}}$ & $33.75^{\mathrm{A}, \mathrm{b}}$ & $10.95^{\mathrm{A}, \mathrm{d}}$ \\
1.5 & $42.75^{\mathrm{CD}, \mathrm{a}}$ & $17.95^{\mathrm{BC}, \mathrm{c}}$ & $25.25^{\mathrm{C}, \mathrm{b}}$ & $8.45^{\mathrm{B}, \mathrm{d}}$ \\
3.0 & $46.00^{\mathrm{BC}, \mathrm{a}}$ & $18.75^{\mathrm{B}, \mathrm{c}}$ & $30.00^{\mathrm{B}, \mathrm{b}}$ & $8.50^{\mathrm{B}, \mathrm{d}}$ \\
4.5 & $37.85^{\mathrm{DE}, \mathrm{a}}$ & $18.15^{\mathrm{B}, \mathrm{c}}$ & $22.00^{\mathrm{CD}, \mathrm{b}}$ & $9.00^{\mathrm{B}, \mathrm{d}}$ \\
6.0 & $29.50^{\mathrm{F}, \mathrm{a}}$ & $13.85^{\mathrm{D}, \mathrm{c}}$ & $18.75^{\mathrm{D}, \mathrm{b}}$ & $6.15^{\mathrm{D}, \mathrm{d}}$ \\
7.5 & $36.35^{\mathrm{DE}, \mathrm{a}}$ & $16.50^{\mathrm{C}, \mathrm{c}}$ & $24.10^{\mathrm{C}, \mathrm{b}}$ & $7.95^{\mathrm{C}, \mathrm{d}}$ \\
\hline
\end{tabular}

MOT/t0: progressive motility in time 0; MOT/t60: in time 60; MOT/t120: in time 120; and MOT/t180: in time 180 of the TRT. A,B,CDifferent upper cases in the same column indicate difference $(P<0.05)$. ${ }^{a, b, c}$ Different lower cases in the same line indicate difference $(P<0.05)$.

Treating goat sperm with $0.75 \mathrm{mg}$ of CLC before cryopreservation resulted in the vigor sperm were higher for sperm samples treated with CLC than control sperm (3.0 and 2.1, respectively; Table 3; $\mathrm{P}<0.05)$.

Table 3: Vigor of reactive spermatozoa treated with CLC or not (0 mg; control) after thermal resistance test at 0,60 , 120 and 180 min of incubation time

\begin{tabular}{lcccc}
\hline CLC $(\mathrm{mg})$ & VIG/t0MIN & VIG/t60MIN & VIG/t120MIN & VIG/t180MIN \\
\hline 0 & $2.11^{\mathrm{B}, \mathrm{a}}$ & $2.00 \mathrm{~B}^{\mathrm{C}, \mathrm{a}}$ & $1.56^{\mathrm{BC}, \mathrm{b}}$ & $1.33^{\mathrm{A}, \mathrm{b}}$ \\
0.75 & $3.00^{\mathrm{A}, \mathrm{a}}$ & $2.78^{\mathrm{A}, \mathrm{ab}}$ & $2.00^{\mathrm{A}, \mathrm{bc}}$ & $1.44^{\mathrm{A}, \mathrm{c}}$ \\
1.5 & $2.11^{\mathrm{B}, \mathrm{a}}$ & $2.11^{\mathrm{BC}, \mathrm{a}}$ & $1.67^{\mathrm{B}, \mathrm{b}}$ & $1.44^{\mathrm{A}, \mathrm{b}}$ \\
3.0 & $2.44^{\mathrm{AB}, \mathrm{a}}$ & $2.11^{\mathrm{BC}, \mathrm{ab}}$ & $1.78^{\mathrm{AB}, \mathrm{b}}$ & $1.44^{\mathrm{A}, \mathrm{b}}$ \\
4.5 & $2.11^{\mathrm{B}, \mathrm{a}}$ & $2.11^{\mathrm{BC}, \mathrm{a}}$ & $1.22^{\mathrm{BC}, \mathrm{b}}$ & $1.11^{\mathrm{AB}, \mathrm{b}}$ \\
6.0 & $1.78^{\mathrm{B}, \mathrm{a}}$ & $1.56^{\mathrm{C}, \mathrm{a}}$ & $1.11^{\mathrm{C}, \mathrm{ab}}$ & $1.00^{\mathrm{AB}, \mathrm{b}}$ \\
7.5 & $2.44^{\mathrm{AB}, \mathrm{a}}$ & $2.22^{\mathrm{AB}, \mathrm{ab}}$ & $1.89^{\mathrm{A}, \mathrm{bc}}$ & $1.33^{\mathrm{A}, \mathrm{c}}$ \\
\hline
\end{tabular}

VIG/t0: progressive motility in time 0; VIG/t60: in time 60; VIG/t120: in time 120; and VIG/t180: in time 180 of TRT. A,B,CDifferent upper cases in the same column indicate difference $(P<0.05)$ for the test SNK. ${ }^{a, b, c}$ Different lower cases in the same line indicate difference $(P<0.05)$ for the test SNK.

Treated semen with 6 and $7.0 \mathrm{mg}$ of CLC demonstrated higher percentage of spermatozoa that swollen tails after the hypoosmotic swelling test compare to the others treatments (Table 4; $\mathrm{P}<0.05$ ).

Table 4: Percentage of spermatozoa treated with CLC or not (0 $\mathrm{mg}$; control) after hypoosmotic test

\begin{tabular}{lc}
\hline Treatment & Swollen tails $(\%)$ \\
\hline $0 \mathrm{mg}$ & $17.60^{\mathrm{ab}}$ \\
$0.75 \mathrm{mg}$ & $17.80^{\mathrm{ab}}$ \\
$1.5 \mathrm{mg}$ & $16.40^{\mathrm{c}}$ \\
$3.0 \mathrm{mg}$ & $17.00^{\mathrm{bc}}$ \\
$4.5 \mathrm{mg}$ & $16.60^{\mathrm{bc}}$ \\
$6.0 \mathrm{mg}$ & $19.50^{\mathrm{a}}$ \\
$7.5 \mathrm{mg}$ & $18.50^{\mathrm{a}}$ \\
\hline
\end{tabular}

$\overline{a, b, c}$ Different superscripts within line indicate treatment differences $(P<0.05)$ for SNK.

CLC treatment resulted in more sperm binding to the chicken egg perivitelline membrane (Figure 1) compared to control sperm $(P<0.05)$.

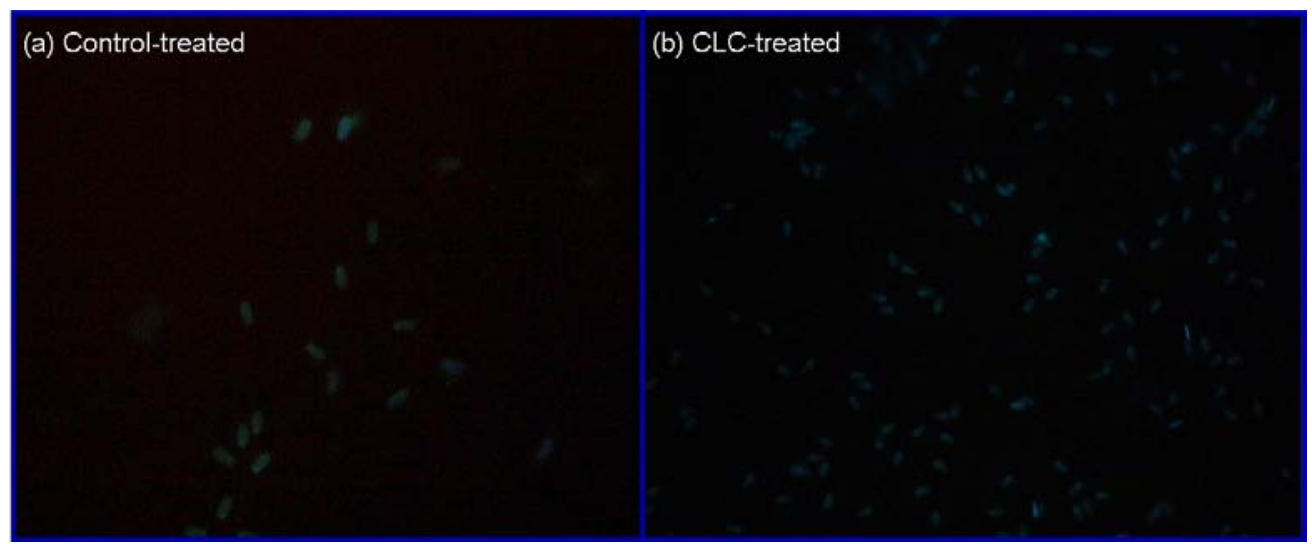

Figure 1: Goat spermatozoa stained with Hoechst 33342 binding to chicken egg perivitelline membrane. a) Spermatozoa of control treatment bound to the membrane. b) Spermatozoa CLC treated bound to the membrane. 
Percentages of number of spermatozoa binding to each were higher for bucks spermatozoa prior to cryopreservation treated with $0.75 \mathrm{mg} \mathrm{CLC} \mathrm{(166;} \mathrm{P<0.05).} \mathrm{However,} \mathrm{when} \mathrm{the}$ spermatozoa binding potential was determined on a motile sperm basis by dividing the average number of spermatozoa bound to PM for each bucks by the percentage of motile spermatozoa, CLC treatment provided higher binding efficiency (1.52) than control (1.00; $\mathrm{P}<0.05)$.

\section{Discussion}

Treating goat sperm with CLC $\left(0.75 \mathrm{mg} \mathrm{CLC} / 120 \times 10^{6}\right.$ sperm) prior to cryopreservation increases the percentages of motile sperm after thawing. Similar results have been previously reported for bull (Purdy \& Graham, 2004a, b; Mocé \& Graham, 2006; Moraes et al. 2010), stallion (Moore et al. 2005; Moraes et al. 2015) and ram (Uçan et al. 2016) sperm using similar CLC concentrations. In addition, this study revealed that sperm treated with cholesterol maintained after cryopreservation the integrity and functionality of plasma membrane.

Purdy et al. (2005) demonstrated that increasing the cholesterol content of bull sperm also increased the fluidity of the sperm's membranes at lower temperatures. In addition, Moore et al. (2005) reported cholesterol-treated stallion sperm exhibited higher membrane permeability than untreated sperm, and that this reduced the osmotic damage, these cells experienced when CPAs were removed.

This study reported that progressive spermatic motility reduced after $3 \mathrm{~h}$ of incubation by thermal resistance test. These results showed a decline in semen quality, without any visible changes in physical and morphological semen aspects, because physical and morphological aspects results were normal.

The average result obtained in this experiment for hypoosmotic test was lower than those described by Santos et al. (2015) and Martins et al. (2010). These authors worked during the spring season in the same herd, which had $57.2 \pm 15$ of reactive sperm cells after hypoosmotic incubation.

Evaluating some of the sperm attributes necessary for fertility, such as the ability of sperm to bind to the zona pellucida may be a tool to assess the capability of a sperm population to fertilize an oocyte (Carrell 2000). However, the molecular similarities between the zona pellucida and the perivitelline membrane of the chicken's egg, sperm from many species, including goat sperm can bind to the perivitelline membrane. Therefore, the development of new or better in vitro assays that can evaluated sperm attributes that are necessary for sperm to fertilize oocytes can prove very useful.

Cryopreservation induces the loss of cholesterol from sperm membranes, causing a type of cryocapacitation (Cormier \& Bailey, 2003). Sperm treated with CLC have higher initial cholesterol concentration in their membranes prior to cooling, and lose lower amounts of cholesterol lost during cryopreservation (Moore et al. 2005). Therefore, the CLC-treated sperm after thawing may prevent these sperm from undergoing a premature capacitation and may increase the longevity of the cryopreserved sperm. However, the additional plasma membrane cholesterol may also affect the ability of the sperm to capacitate and undergo an acrosome reaction (Purdy \& Graham, 2004a). Attempting to load sperm with compounds, other than cholesterol, that may alter membrane permeability to CPAs, lower membrane transition temperatures and increase membrane fluidity, may permit increased cryosurvival rates, without altering the rate of sperm capacitation and cholestanol-treated sperm survived cryopreservation similarly to cholesterol-treated sperm.

In addition, cholesterol-treated sperm were capable of binding to the EPM better than control sperm. However, additional studies are needed to determine if adding cholesterol to sperm membranes alters their ability to capacitate, undergo an acrosome reaction and fertilize oocytes.

\section{Conclusion}

Adding $0.75 \mathrm{mg}$ of cholesterol to goat sperm prior to cryopreservation improved cell cryosurvival rates and improved sperm motility after cryopreservation for up to 2 hours. Cholesterol-treated goat sperm can bind to chicken perivitelline membranes in vitro more efficiently than control sperm. However, further studies need to be conducted to determine if cholesterol addition affects sperm capacitation and acrosome reaction after cryopreservation.

\section{Acknowledgments}

The FACEPE (Foundation of the state of Pernambuco), from Brazil, for the financial support by APQ-0227-5.04/10 (Project). The FACEPE and CNPq (National Counsel of Technological and Scientific Development), from Brazil, for the scholarship scientist researches (Pibic).

\section{References}

Barbato G.F., Cramer P.G., Hammerstedt R.J. A practical in vitro sperm-egg binding assay that detects subfertile males. Biology of Reproduction, v. 58, n. 3, p. 686-699, 1998.

Carrell D.T. Semen analysis at the turn of the century: an evaluation of potential uses of new sperm function assays. Archives of Andrology, v. 44, n. 1, p.65-75, 2000.

Cormier N., Bailey J.L. A differencial mechanism is involved during heparin- and cryopreservation-induced capacitation. Biology of Reproduction, v. 69, p. 177-185, 2003.
Graham J.K., Foote R.H., Parrish J.J. Effect of dilauroyphosphatidylcholine on the acrosome reaction and subsequent penetration of bull sperm into zona-free hamster eggs. Biology of Reproduction, v. 35, p. 413-424, 1986.

Köppen-GeigerPeel M.C., Finlayson B.L., \& McMahon T.A. Updated world map of the Köppen-Geiger climate classification. Hydrol. Earth System Science, v. 11, p.1633-1644, 2007.

Lee Y.S., Lee S., Lee, S.H., Yang B.K., Park C.K. Effect of cholesterol-loaded-cyclodextrin on sperm viability and acrosome reaction in boar semen cryopreservation. Animal Reproduction Science, v. 159, p.124-130, 2015. 
Martins L.F., Baracat-Pereira M.C., Guimaraes J.D., Guimaraes S.E.F., Pinh, R.O. Semen quality and concentration of soluble proteins in the seminal plasma of Alpine bucks. Revista Brasileira de Saúde e Produção Animal, v. 1, n. 2, p. 547-554, 2010.

Melo M.I.V. \& Henry M. Teste hiposmótico na avaliação de sêmen equino. Arquivo Brasileiro de Medicina Veterinária e Zootecnia, v. 51, p. 71-78, 1999.

Mocé E., Graham, J.K. Cholesterol-loaded cyclodextrins added to fresh bull ejaculates improve sperm cryosurvival. Journal of Animal Science, v. 84, p. 826-833, 2006.

Mocé E., Blanch E., Tomás C., Graham J.K. Use of cholesterol insperm cryopreservation: present moment and perspectives to future. Reproduction in Domestic Animals, v. 45, n. 2, p.57-66, 2010a.

Mocé, E.; Purdy, P. H.; Graham, J. K. Treating ram sperm with cholesterol-loaded cyclodextrins improves cryosurvival. Animal Reproduction Science, v. 118, p. 236-247, 2010b.

Moore A.I., Squires E.L., Graham J.K. Adding cholesterol to the stallion sperm plasma membrane improves cryosurvival. Cryobiology, v. 5, p. 241-249, 2005.

Moraes E.A., Graham J.K., Torres C.A.A., Meyers M., Spizziri B. Delivering cholesterol or cholestanol to bull sperm membranesimproves cryosurvival. Animal Reproduction Science, v.118, p. 148-154, 2010.

Moraes E.A., Matos W.C.G., Graham J.K.; Ferrari Junior W.D. Cholestanol-loaded-cyclodextrin improve the quality of stallion spermatozoa after cryopreservation. Animal Reproduction Science, v. 158, p.19-24, 2015.

Müller, K.; Müller, P.; Pincemy, G.; Kurz, A.; Labbe, C. Characterization of sperm plasma membrane properties after cholesterol modification: consequences for cryopreservation of rainbow trout spermatozoa. Biology of Reproduction, v. 78, p. 390-399, 2008.
National Requirement Council - NRC. Nutrient Requirements of Small Ruminants: Sheep, Goats, Cervids, and New World Camelids. National Academy of Science,Washintgton, D.C. 347 p., 2007.

Neild D.M., Chaves M.G., Flores M., Miragaya M.H., Gonzalez E. \& Aguero A. The HOS test and its relationship to fertility in the stallion. Andrologia, v. 32, p.351-355, 2000.

Purdy P.H., Graham J.K. Effect of adding cholesterol to bull sperm membranes on sperm capacitation, the acrosome reaction, and fertility. Biology of Reproduction, v. 71, p. 522-527, 2004a.

Purdy P.H., Graham J.K. Effect of cholesterol-loaded cyclodextrin on the cryosurvival of bull sperm. Cryobiology, v. 48, p. 36-45, 2004b.

Purdy P.H., Fox M.H., Graham J.K. The fluidity of Chinese hamster ovary cell and bull sperm membranes after cholesterol addition. Cryobiology, v. 51, p.102-112, 2005.

Santos M.A.M., Gradela A., Moraes E.A., Souza W.L., Alves N.G., Costa J.M.S., Matos W.C.G. Características do sêmen a fresco e descongelado de garanhões da raça Nordestina. Pesquisa Veterinária Brasileira, v. 35, n. 11, p. 925-932, 2015.

SAS Institute Inc., SAS User's Guide: Statistics, SAS Institute Inc., Cary, NC, 2008ed.

Uçan U., Küçük N., Ahmad E., Naseer Z., Aksoy M., Serin I., Ceylan A. Effect of different sugars supplemented to the extender in combination with cholesterol-loaded cyclodextrin (CLC) on post-thaw quality of ram spermatozoa. Small Ruminant Research, v. 136, p. 243-246, 2016.

Yildiz, C., Yavas, I., Bozkurt, Y., Aksoy, M.. Effect of cholesterolloaded cyclodextrin on cryosurvival and fertility of cryopreserved carp (Cyprinus carpio) sperm. Cryobiology, v. 70, p. 190-194, 2015. 